\title{
GOOGLE TAX: HOW TO AVOID STEPPING BACK IN THE NEAR FUTURE?
}

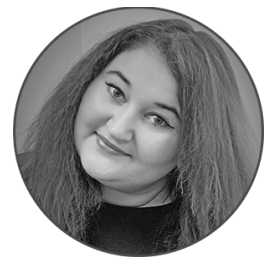

Article history:

Received 30 July 2018

Received in revised form

10 August 2018

Accepted 17 August 2018

Translated 16 November 2018

Available online 24 December 2018

JEL classification: $\mathrm{H} 22, \mathrm{H} 25$

Keywords: VAT, Google tax, tax administration, electronic services, Internet
ANNA V.TIKHONOVA

Financial University under Government of Russian Federation, Moscow, Russian Federation AVTihonova@fa.ru

The editor-in-charge of this article was Irina M. Vechkanova

Authorized translation by Andrey V. Bazhanov

\section{Introduction}

Since January 1, 2017, the Russian Federation has introduced the so-called Google tax, which involves the Value Added Tax (VAT) taxation of electronic services providers to Russia. The main objective of this legislative initiative was to involve foreign companies providing electronic services to Russian consumers (primarily, natural persons) in the national legal tax field [1-3].

Currently, the tax authorities are only observing the process of registration and payment of VAT.

According to official information of the Federal Tax Service of the Russian Federation (RF FTS), 163 foreign

${ }^{\dagger}$ For the source article, please refer to: Тихонова А.В. Налог на Google: как не сделать шаг назад в ближайшем будущем? Международный бухгалтерский учет. 2018. Т. 21. № 10. С. 1129-1139. URL: https://doi.org/10.24891/ia.21.10.1129 companies from 29 countries are officially registered as taxpayers on the FTS website in the VAT office, as of July 27, 2018. Among the category under consideration, only five taxpayers have been registered in 2018 (Table 1).

The results of the RF FTS declaration campaign for 2017 showed that the total VAT proceeds in the Federal budget from foreign suppliers of Internet services amounted to RUB 9.34 billion. No doubt, this is a significant amount for the budget of the Russian Federation, but the tax potential of this industry is much higher [4-6].

According to economic experts, the industry is able to bring about RUB 182 billion of VAT payment in the RF consolidated budget [7]. The first two years of the existence of the Google tax show significant legislative and technical gaps that affect the quality of 
administration of this tax and revenue amount to the budget considerably [8].

That is why the Ministry of Finance of the Russian Federation and RF FTS published more than 45 explanatory letters in 2017. In addition, rather significant changes are to be introduced in the tax structural quality after January 1, 2019. This determines the relevance of this study.

\section{The General Rules of Electronic Service VAT Taxation from January 1, 2019}

The general concept of taxation rules (up to January 1, 2019) assumes that a foreign organization providing electronic services to individuals, is to pay the Value Added Tax in the Russian Federation [9]. For this purpose, the Russian national legislation provides a special procedure for registration of foreign organizations with the Russian tax authorities ${ }^{1}$.

At present, when supplying electronic services, foreign organizations should be registered with the tax authorities to assess VAT, if the customer of services is a natural person (Fig. 1).

The exception to this order is the situation when a foreign organization renders such services through its subdivisions opened in Russia. In such a case, there is no need to register with the tax authority. Separate subdivisions are already registered in tax inspections and pay VAT to the budget independently.

However, as of January 1, 2019, the foreign organization supplying electronic services will be vested with the obligation to assess VAT, regardless of who is the customer. According to the adopted law, the current mechanism of tax agent in providing electronic services by foreign organizations to organizations and individual entrepreneurs, registered with the Russian tax authorities, is excluded.

Starting from January 1, 2019, foreign providers of electronic services, as well as foreign agencies, involved in payments with Russian taxpayers that purchase electronic services, will be required to register for VAT payment in respect of such service delivery (B2B) [10].

Until February 15, 2019, foreign organizations providing electronic services to organizations and individual entrepreneurs registered with the Russian tax

\footnotetext{
${ }^{1}$ From January 1, 2018, Russian organizations that are subjects of the national payment system (including telecom operators) and performing intermediary activities on settlements (transfer of funds) with customers of electronic services, are not recognized as tax agents.
}

authorities (including, for instance, branches of foreign organizations), will have to submit an application for the registration to pay VAT. The registration is mandatory even if the services rendered are exempt from VAT in Russia (for instance, granting rights to use software under the license agreement).

From January 1, 2019, foreign organizations that are already registered and paying VAT in relation to electronic services rendered to Russian customers, namely natural persons, will have to assess and pay VAT in the same way from deliveries to Russian taxpayers, namely organizations and individual entrepreneurs.

\section{Peculiarities of Electronic Service VAT Taxation}

Paragraph 1 of Article 174.2 of the Tax Code of the Russian Federation (RF Tax Code) defines 16 types of electronic services, rendering of which through the Internet to Russian users is subject to taxation ${ }^{2}$.

These services are conditionally divided into the following groups.

\section{Advertising and Promotion:}

- advertising services;

- placement of offers on purchase of goods, works, services;

- services to provide opportunities to forge partnerships between buyers and sellers;

- services on search and/or presentation of the information on potential buyers to the customer.

\section{Internet Data Processing:}

- granting rights to use software, databases;

- information storage and subsequent processing;

- providing capacity to store data;

- providing access to search engines;

- services on data retrieval, selection and sorting;

- granting rights to use cultural and educational data.

\section{Internet Work-Related Services:}

- presence in the network, support of electronic resources, providing access to resources;

\footnotetext{
${ }^{2}$ According to the Tax Code of the Russian Federation, any provision of services in electronic form means rendering services in an automated fashion, using information technologies through the information and telecommunication network, including the Internet.
} 
- information systems administration;

- granting domain names, rendering hosting services;

- collecting statistics on websites.

The sale of goods, implementation of software with no data on tangible media, and the provision of consulting services via e-mail, and Internet access services are not included in the previous list [11].

The rule to determine the place of rendering of services is described in Subparagraph 4 of Paragraph 1 of Article 148 of the RF Tax Code. At the same time, Paragraph 3 of Article 148 of the RF Tax Code notes that the place of implementation of related services (works) is determined at the place of realization of basic services (works). The place of implementation of electronic services through the Internet is defined in a special way (Fig. 2).

In the case of such a category of electronic service purchasers, as individuals who are not individual entrepreneurs, a special procedure for determining the location is established.

For instance, when a non-individual entrepreneur's purchasing digital services via the Internet, the Russian Federation shall be the place of services delivery if:

- the natural person resides in the Russian Federation;

- the bank that opens the account for the services payment or the e-money service business are located in the Russian Federation;

- the IP address of the customer purchasing the services is registered in the Russian Federation;

- the International dialing code belongs to the Russian Federation (if services are paid via phone).

There are serious problems in this area that hinder effective VAT administration. For instance, at the moment, it is not clear how the online store can determine the location of the e-service purchaser [12].

The IP address of the individual purchasing the service will fail to answer this question unambiguously, even. The point is that the proxy server is able to transmit traffic absolutely through any country (even through a chain of countries) at the choice of the service purchaser. The service supplier will also locate the specified country as the source of the service request.

In addition, a great number of goods and services via the Internet is currently purchased using electronic wallets. As a result, the bank or e-money service operator's location is sometimes impossible to identify, especially if there is no customer's telephone number.

Thus, certain technical aspects do not allow the customer to qualitatively perform VAT payment duties, even if there is a due and right wish of the taxpayer, foreign service provider, to do so.

To pay VAT, it is not necessary to open a current account in a Russian bank. This tax can be paid from any other account opened in a commercial bank located outside the Russian Federation.

If a tax agent participates in the sales chain, he/she performs the duties of assessing and paying VAT to the budget. In such a situation, the tax agent may claim a VAT credit, provided that:

- the tax agent is the VAT payer. Hence the conclusion is that taxpayers applying special tax regimes cannot claim a VAT credit for the VAT paid on electronic services;

- goods, works, services are purchased for VAT taxable operations;

- the VAT amount is deducted from the money paid to the foreign company and transferred to the budget.

From January 1, 2019, documentary confirmation of the service implementation place will also be changed for organizations and individual entrepreneurs. In accordance with the current edition of the RF Tax Code, such documents are as follows:

- Contracts concluded with foreign or Russian entities;

- Documents confirming the fact of performance of works (rendering of services).

According to the new rules, the service implementation place concerning individuals, organizations and individual entrepreneurs will be confirmed in the same way, i.e. on the basis of transaction registers indicating information on fulfilment of the conditions stipulated in the second and fourteenth to seventeenth passages of Subparagraph 4 of Paragraph 1 of Article 148 of the RF Tax Code.

\section{The Current State and Issues of Electronic Service VAT Operations}

As it was noted, starting from January 1, 2019, regardless of the organizational and legal form, any foreign organization shall be obliged to register with the tax authorities if implementing electronic services to economic entities in the territory of the Russian 
Federation. For this purpose, a new scheme of simplified registration as a VAT payer has been introduced into the tax legislation.

The scheme of registration is quite simple: a foreign organization must submit the relevant application and other documents ${ }^{3}$ within 30 calendar days starting from January 1 and no later than 30 calendar days from the date of commencement of electronic services supply to the Russian customers.

Documents may be submitted in common ways. This can be done personally, through a representative, or by registered mail. However, the most convenient option is an electronic registration via the RF FTS website, with no enhanced encrypted and certified digital signature required. After that within 30 calendar days, the tax authority registers the foreign organization and notifies it about this.

To simplify the procedure of VAT operations and ensure the transparency treatment of VAT assessment, the RF FTS has developed and offers a taxpayer profile account option for foreign organizations that supply electronic services in the Russian Federation ${ }^{4}$.

It is important to note that the documents submitted to the tax authority through the taxpayer profile account and enhanced encrypted and non-certified digital signature signed, are recognized as electronic documents equivalent to hard copies signed by a representative of such an organization with his/her own hand.

The VAT special tax return is the main document administered by the RF FTS for this category of taxpayers. In fact, it consists of two sections: VATable transactions and non-VATable transactions ${ }^{5}$. In this case, the purchase and sales ledgers, as well as the journals of VAT invoices received and issued for electronic services implementation are not assembled by foreign suppliers ${ }^{6}$.

The legislation also defines some peculiarities concerning the procedure of in-house tax control (Table 2).

It should be noted that the possibility of requesting information on money transfers to the accounts of foreign organizations within the national payment

\footnotetext{
${ }^{3}$ The list of documents is subject to approval by the Ministry of Finance of the Russian Federation.

${ }^{4}$ The RF Tax Code, Para. 3, Art. 11.2.

${ }^{5}$ In accordance with the RF Tax Code, Subpara. 26, Para. 2, Art. 149.

${ }^{6}$ The RF Tax Code, Para. 3.2, Art. 169.
}

systems is an important tool of tax management. It contributes to the determination of the real amount of revenues from the provision of electronic services in the territory of the Russian Federation, especially if there are technical deficiencies in determining the place of implementation of services (as noted before).

However, this approach can be applied only to the digital market majors, while the issue of effective administration of small foreign companies is still a pending one. Therefore, tax management comes down to the analysis of the information submitted by taxpayers, and it is not always true and reliable [13].

In addition, it was previously noted that the availability of a bank account in the Russian Federation is not mandatory for registration with the tax authorities. In this regard, it is not clear how to prosecute a foreign taxpayer in case of detecting the fact of committing an offence, if the majority of foreign taxpayers does not have any property in Russia.

And finally, one of the most significant problems in the e-services VAT tax management is a new transition to tax payment by foreign suppliers in the B2B segment. The matter is that the approach like this will cause an unbalance in foreign companies' VAT payments on electronic and other services rendered in the territory of the Russian Federation. In fact, this creates additional administrative barriers and hinders the development of foreign digital markets in Russia.

\section{Conclusions}

The analysis shows that significant legislative and technical problems hinder the successful development of a mechanism of e-services VAT tax implementation. However, the tax changes in this area expected from January 1, 2019, in our opinion, will further aggravate the unregulated nature of tax management.

We believe that the improvement of taxation and tax management of foreign suppliers of electronic services is possible only under appropriate reference to the most advanced international practices, first of all, the ones of the EU countries [14-16]. For instance, the $\mathrm{B} 2 \mathrm{~B}$ segment uses the Reverse Charge VAT mechanism, which involves the transfer of the seller's tax payment to the purchaser, with the simultaneous acceptance of VAT to be paid by the latter.

This mechanism is not just taxpayer convenient, but it also helps reduce the risk of fraud in the field of Internet service trade, making it a minor one. 


\section{Table 1}

Number of foreign e-service supply VAT payers

\begin{tabular}{lll}
\hline Country & Number of Taxpayers & $\begin{array}{l}\text { Overall } \\
\text { Number } \\
\text { Ratio } \\
\text { (Percentage) }\end{array}$ \\
\cline { 2 - 3 } & 45 & 17.2 \\
\hline United Kingdom & & 12.9 \\
\hline Ireland & 28 & 10.4 \\
\hline Germany & 21 & 6.7 \\
\hline Netherlands & 17 & 3.7 \\
\hline Luxembourg & 11 & 3.1 \\
\hline Switzerland & 6 & 2.5 \\
\hline Cyprus & 5 & 1.8 \\
\hline France & 4 & \\
\hline
\end{tabular}

Source:Authoring based on the Federal Tax Service of the Russian Federation data. URL: https://kioreg.nalog.ru/ru/registry

\section{Table 2}

Peculiarities of office tax audit of foreign e-service suppliers

\begin{tabular}{lll}
\hline Audit Criterion & Standard Inspection Procedure & When E-Services Providing by Foreign Suppliers \\
\hline Auditing all-in term & Three months maximum & Six months maximum \\
\hline Failure to file a tax return & - & $\begin{array}{l}\text { The tax authority shall send a notice within } 30 \text { calendar } \\
\text { days from the date of expiry of the deadline } \\
\text { for submission }\end{array}$ \\
\hline $\begin{array}{l}\text { Deadline for submission of documents } \\
\text { from the date of requirements receipt }\end{array}$ & Ten days & Thirty days \\
\hline Request for information & - & $\begin{array}{l}\text { The tax authority, subject to the consent of the FTS Head } \\
\text { (Deputy head), may request information on remittances } \\
\text { to the accounts of a foreign organization }\end{array}$ \\
\hline
\end{tabular}

Source:Authoring based on the Tax Code of the Russian Federation 
Figure 1

A general procedure of VAT computation and payment when supplying e-services till January 1, 2019

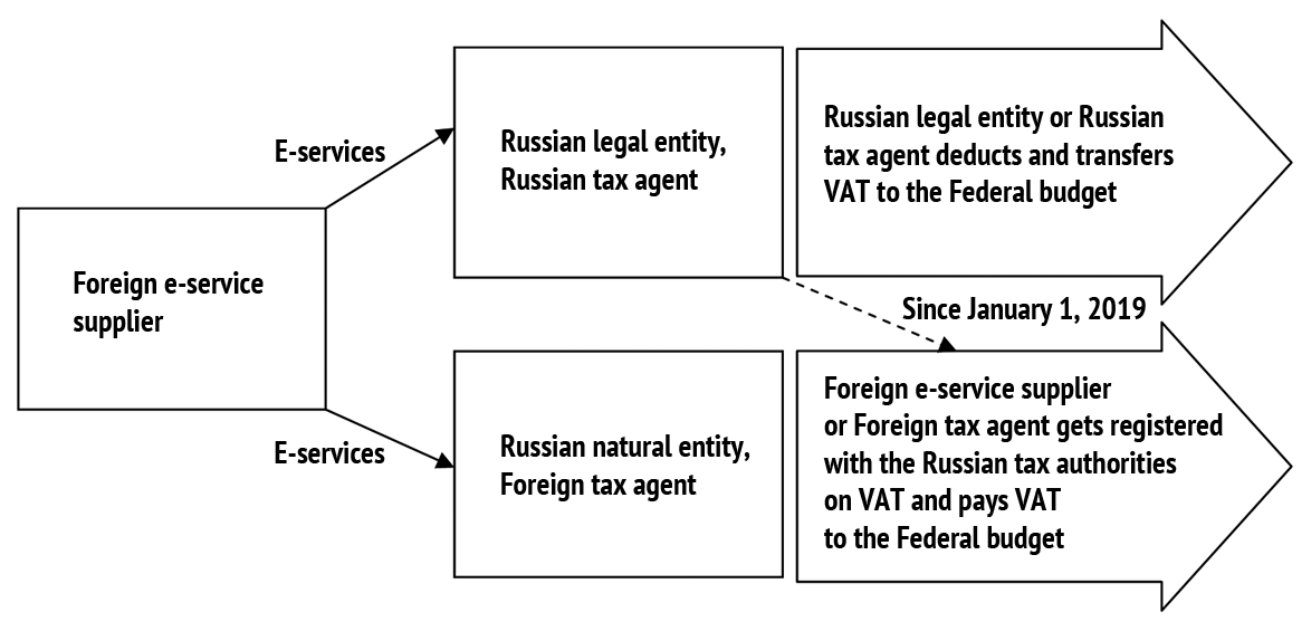

Source:Authoring

Please cite this article as: Tikhonova A.V. Google Tax: How to Avoid Stepping Back in the Near Future? 
Figure 2

Service location for VAT computation

\begin{tabular}{|c|c|}
\hline According to the property location & $\begin{array}{l}\text { - Services related to immovable or movable property (including rent and lease) } \\
\text { - Services related to movable property, vehicles }\end{array}$ \\
\hline $\begin{array}{l}\text { According to the customer's occupation } \\
\text { location/jurisdiction (on the basis } \\
\text { of State registration or other fact reflected } \\
\text { in the founding documents) }\end{array}$ & $\begin{array}{l}\text { - Consulting, legal, accounting, auditing, engineering, advertising, marketing } \\
\text { services, and information processing and R\&D services } \\
\text { - Personnel services (the staff works at the customer's place of business) } \\
\text { - Services for transfer, granting of patents, licenses, trademarks, copyrights } \\
\text { or other similar rights, development of computer programs and databases } \\
\text { - Lease of movable property } \\
\text { - Services rendered electronically to the subjects of the Russian economy } \\
\text { - Transportation services } \\
\text { - If the activity of an organization or individual entrepreneur providing } \\
\text { services is carried out in the territory of the Russian Federation }\end{array}$ \\
\hline $\begin{array}{l}\text { According to the de facto service rendering } \\
\text { and work performance }\end{array}$ & $\begin{array}{l}\text { - Works (services) in the field of culture, art, education (training), physical } \\
\text { culture, tourism, recreation, and sports } \\
\text { - Services in the field of geological exploration and production of raw } \\
\text { hydrocarbon materials on subsurface sites, located in whole or in part } \\
\text { on the continental shelf and/or in the exclusive economic zone of the Russian } \\
\text { Federation }\end{array}$ \\
\hline $\begin{array}{l}\text { According to the supplier's occupation } \\
\text { location/jurisdiction }\end{array}$ & $\begin{array}{l}\text { Services for which there are no specific rules for determining } \\
\text { the place of services supply }\end{array}$ \\
\hline
\end{tabular}

Source:Authoring based on the Tax Code of the Russian Federation

\section{Acknowledgments}

The article was prepared on the basis of the results of studies supported by budgetary funds under State job to the Financial University under the Government of the Russian Federation, 2018.

\section{References}

1. Milogolov N.S., Berberov A.B. [An analysis of the effectiveness of VAT tax benefit for IT companies]. Nalogi i nalogooblozhenie = Taxes and Taxation, 2017, no. 11, pp. 18-26. (In Russ.)

2. Akhmadeev R.G., Bykanova O.A., Malakhova L.I. [Digital content market: new rules of payment for the VAT]. Azimut nauchnykh issledovanii: ekonomika i upravlenie = ASR: Economics and Management, 2017, vol. 6, no. 4, pp. 43-46. URL: https://cyberleninka.ru/article/n/rynok-tsifrovogo-kontenta-novyy-poryadok-vzimaniya-nds (In Russ.)

3. Bozov A.A. [Taxation of VAT of electronic services (tax on Google)]. Vestnik professional'nogo bukhgaltera= The Messenger of Professional Accountants, 2017, no. 1-3, pp. 83-88. (In Russ.) 
4. Em A.V. [The main directions of improving the system of Value Added Tax collection when foreign entities provide services on-line]. Aktual'nye problemy rossiiskogo prava, 2018, no. 3, pp. 77-86.

URL: https://cyberleninka.ru/article/n/osnovnye-napravleniya-sovershenstvovaniya-sistemy-vzimaniya-nalogana-dobavlennuyu-stoimost-pri-okazanii-inostrannymi (In Russ.)

5. Sotnikova L.V. [Electronic services: taxation on value added]. Bukhuchet $v$ stroitel'nykh organizatsiyakh= Accounting in Construction Companies, 2017, no. 4, pp. 57-63. (In Russ.)

6. Makarov V.S., Cherneva Yu.A., Kazakova N.A. Nalog na Google kak istochnik privlecheniya dopolnitel'nykh denezhnykh sredstv $v$ byudzhet. $V$ kn.: Finansovye strategii i modeli ekonomicheskogo rosta Rossii: problemy $i$ resheniya. Sb. nauch. statei [Tax on Google as a source of attracting additional funds to the budget. In: Financial strategies and models of Russia's economic growth: problems and solutions. A collection of scientific articles]. Moscow, Auditor Publ., 2017, pp. 103-112. URL: https://www.rea.ru/ru/news/SiteAssets/sbornik-nauchnyhstatej.pdf

7. Sennaya I.K. [Improvement of taxation of e-commerce as the most perspective sphere of the Russian economy]. Nauchno-prakticheskie issledovaniya, 2017, no. 2, pp. 236-239. (In Russ.) URL: http://deltascience.ru/j/spr-2017-02.pdf

8. Borisichev A.A., Korshakova D.M. [Google Tax: controversies in practice]. Nalogoved, 2017, no. 6, pp. 38-47. (In Russ.)

9. Shamsutdinova V.Sh. [Features of calculation and collection of VAT on the sale of foreign companies of electronic services to Russian consumers]. Ekonomika i menedzhment innovatsionnykh tekhnologii, 2017, no. 2, pp. 120-122. (In Russ.) URL: http://ekonomika.snauka.ru/2017/02/14075

10. Kabanov I.P. [Models of tax and other payments collection in cross-border electronic commerce]. Rossiiskii vneshneekonomicheskii vestnik = Russian Foreign Economic Journal, 2017, no. 10, pp. 56-68.

URL: https://cyberleninka.ru/article/n/modeli-vzimaniya-nalogov-i-inyh-platezhey-v-ramkah-transgranichnoyelektronnoy-torgovli (In Russ.)

11. Glebova O.P. [Tax on Google and the responsibilities of Russian people]. Nalogovaya politika i praktika= Tax Policy and Practice, 2017, no. 7, pp. 44-48. (In Russ.)

12. Milogolov N.S. [Problems and prospects of VAT taxation for international supply of digital services]. Nalogovaya politika i praktika = Tax Policy and Practice, 2014, no. 5, pp. 74-79. (In Russ.)

13. Mitin D.A. [Features of tax administration of electronic commerce in the Russian Federation]. Upravlenie ekonomicheskimi sistemami: elektronnyi nauchnyi zhurnal, 2018, no. 5. (In Russ.)

14. Milogolov N.S. [Administration of VAT in the field of e-commerce: the experience of EU countries]. Vestnik AKSOR = AKSOR Bulletin, 2015, no. 3, pp. 31-33. (In Russ.)

15. Astakhov K.G. [OECD Report on Effective VAT Collection: Perspectives of application in Russia]. Nalogoved, 2017, no. 12, pp. 44-50. (In Russ.)

16. Sokolovskaya E.V. [Indirect taxation of cross-border transactions in electronic commerce]. Ekonomika i upravlenie = Economics and Management, 2017, no. 8, pp. 37-47. (In Russ.).

\section{Conflict-of-interest notification}

I, the author of this article, bindingly and explicitly declare of the partial and total lack of actual or potential conflict of interest with any other third party whatsoever, which may arise as a result of the publication of this article. This statement relates to the study, data collection and interpretation, writing and preparation of the article, and the decision to submit the manuscript for publication. 